\title{
Cultural Introduction in Japanese Teaching
}

\author{
Yu Aibo \\ Jiangxi College Of Foreign Studies
}

\begin{abstract}
As we all know, language is the tool of human beings for communication. Culture is a complex social phenomenon and is intimately connected with language, while the use of language is for communication, so it is must to understand the language cultural background for a better use of the language. To truly master a foreign language, it is necessary to know the culture of it and the differences between it with the dominate culture, otherwise it can not be said to master the language. Therefore, the language learning process is too the process of cultural learning. This essay states out the contents and the methods of cultural introduction in Japanese teaching through analyzing the relationship among language, culture and communications. The paper too analyzes existing problems of cultural introduction in Japanese teaching and puts forward the countermeasures to solve these problems.
\end{abstract}

Keywords-Japanese Teaching; Japanese; Cultural Introduction; Japanese Viewpoint

\section{INTRODUCTION}

China and Japan are neighbors separated only by a strip of water, and have a long - standing cultural communication history. Especially for Japanese culture is deeply influenced by Chinese traditional culture, so some people thinks there are only small differences between them two cultures, and which is actually a little bit one-sided. Because of its unique historical and geographic environment and other factors, Japan is formed with unique cultures. If using the Chinese thinking to understand the Japanese words, it will inevitably cause misunderstanding between the two sides that it can not correctly and fully give play to the role of language in communication. Consequently in the process of Japanese learning people must understand Japanese national characters and the cultural differences between China and Japan and communicate by the special thinking way of Japanese. As Japanese learners, they must correctly grasp the social cultural background behind the language at the same time with learning language form and structure, and only in this way shall they correctly us Japanese to communicate.

Along with the influence from the global integration to our country, intercultural communication has got more and more attention, more and more Japanese education scholars have realized the importance of culture teaching, college Japanese teaching class has introduced the cultural content, however, there are still some problems remaining to be solved in actual process of teaching, people must study the ways to solve these problems.

The paper studies the background and the purpose and sums up some research results studied out before. It states the necessity of cultural importing in Japanese teaching through analyzing cultural introduction in English teaching and Japanese teaching.

\section{RELATIONSHIP BETWEEN LANGUAGE AND CULTURE}

Some people says: "it is easy to learn Japanese, for the meaning of this sentence can be roughly known by seeing the Chinese characters in the Japanese", but it actually is not the truth. Although Japanese is highly affected by the Chinese, even the source of the letters in Japanese - kana is imitated from character component canopy of Chinese characters or using cursive script creation in the Chinese and the Japanese characters is also from mandarin, after a long period of evolution, Japanese turns to be a completely independent language that is different from Chinese. Any of the languages is used by people living in certain area of language using and by spoken or written language form and use of mutual communication. At the same time, a particular language is always closely bound up with nationality or the country using the language and its history, culture and social background.

Cultural linguists believe that the relationship between language and culture are closely, the role and influence of them is commutative and dialectical. On one hand, language is the foundation of culture forming, a record of 
cultural symbols, and the important carrier of culture. On the other hand, culture is the power of language creation and the content of expression and it stipulates people's language concept, "culture restricts the production and the development direction of language, so that the national languages get their own cultural characteristics and forms the characteristics which is different from other languages". Language is the most common and important tool for people to communicate in the social life. Since each society has its specific culture, therefore, the language used by social members for communication inevitably reflects its culture, so far as to say that "to a great extent, the language is the product of culture, Culture and language are inseparable". Like the language of other ethnic groups, in the process of Japanese language formation and development, Japanese culture plays a decisive guidance and restrictive function.

\section{THE VIEWPOINT OF JAPANESE}

Self expression in Japanese is one of the difficulties in learning performance. The reasons for this is often not because of the vague of differences in morphology and semantic usage, but because of the learners do not think from the Japanese perspective to capture and thinking for the event. As for domestic language learners, it is more apparent because of the limitations of language environment, and they do not give a corresponding attention on this.

"Viewpoint" is one of the characteristics of Japanese and too indispensable important component of the acquisition contents. It is relatively complex for Japanese self expression which examined from the angle of viewpoint. Viewpoint is a focal point of things and is related to the way of people to know the world and the angle to see things. For the same language, if with different viewpoints and opinions, there are different expression methods when through language expressing. Japanese is a viewpoint-sensitive language, active and passive sentences, moving toward subsidies verbs, teaching subject relationship sentences, and other forms of expression shows the position and orientation of the speaker. Viewpoints and the study of Japanese language provide a new angle of view for the study of language typology and speech act and a powerful reference for Japanese education.

\section{JAPANESE SOCIAL CULTURE INTRODUCTION IN JAPANESE EDUCATION}

In actual Japanese linguistic teaching process, the traditional grammar translation method and structure analysis method are always used, and teachers emphasize the teaching focal point on Japanese knowledge and generally vocabulary teaching, grammar analysis and sentence practicing is their teaching model, which pays over attention on Japanese grammar analysis and the mastery of three elements such as pronunciation, vocabulary and grammar, and which puts their most energy into the aspects like: Japanese sentence and grammar teaching, substitution practice, reading and the ability of taking tests and so on, and which lays particular stress on reading and understanding ability and fluency of oral Japanese but ignores the context, pragmatic and other issues, and which dose not give due attention on students' nonverbal behavior, cultural identification ability and intercultural communication ability. All these make the students lack of the ability to use appropriate language in the proper place when they are in communication that they consequently make a joke and cause the failure of communication because they can not flexibly use Japanese according with the situation or they even take use of the verbal communicate standard of Chinese culture to apply to Japanese. In addition, when they practice the sentences patterns, the students just normally make mechanical reading but ignoring the nonverbal behaviors in communication such as gestures, posture, and facial expressions and so on, and this naturally cause the students an insincere impression in communication.

Although all the students' grasp of Japanese knowledge can reach the level of taking the five basic technologies: listening, speaking, reading, writing and translating according to the requirements of the syllabus in Japanese teaching, they often get misunderstanding when they actually use Japanese to communicate because they do not understand Japanese social and culture knowledge. In consequence, the students need not only to learn the basic language knowledge as pronunciation, vocabulary and grammar but also to get familiar to Japanese social and culture, so as to achieve the fundamental goal of cultivating students' correct use of Japanese and upgrading their cross-cultural communication ability. 


\section{CONCLUSION}

As for the six basic methods of introducing Japanese culture into Japanese teaching, there are three principles must to be obey for each of them: practical, periodical and suitable. Inputting cultural contents should keep close link with the main aspects of learning contents and daily communication and at the same time should consider the factor about professional characters that students will take; also it should keep pace with students' language level, and the ability to accept and understand; the teaching methods should be appropriate, and the contents should be moderate.

In conclusion, in Japanese teaching process, people should pay a focal attention on the differences between Chinese-Japanese culture and should understand and study on these. As a Japanese language teacher, they should not only help students with learning Japanese as a language but also take variety forms to help students understand Japanese social and cultural knowledge, only then can the students constantly enrich and expand Japanese social and cultural knowledge at the same time when they learn the Japanese language knowledge, and can they expand the Japanese knowledge and enhance their sensibility on Chinese-Japanese cultural differences and avoid some pragmatic errors caused by cultural differences, so as to correctly use Japanese in communication and upgrade cross-cultural communication skills.

\section{REFERENCES}

[1] Langlois, Richard N., and W. E. Steinmueller. "Strategy and circumstance: the response of American firms to Japanese competition in semiconductors, 1980-1995." Strategic Management Journal 21.10-11(2000):1163-1173.

[2] Nonaka I, Takeuchi H. The knowledge-creating company : how Japanese companies create the dynamics of innovation[M]// Oxford University Press, 1995:592.

[3] Katayama, H., Yamaguchi, K., Kozuka, T., Takashima, T., Seez, P., \& Matsuura, K. (1990). Adverse reactions to contrast media: ionic versus nonionic: a report from the japanese committee on the safety of contrast media. Radiology, 175.

[4] Shigenori M, Yukio I, Gaku K, et al. Paleogeographic maps of the Japanese Islands: Plate tectonic synthesis from $750 \mathrm{Ma}$ to the present[J]. Island Arc, 2006, 6(1):121-142.

[5] Hou, Jilun, et al. "Cytological studies on induced meiogynogenesis in Japanese flounder Paralichthys olivaceus (Temminck et Schlegel)." Aquaculture Research 40.6(2008):681-686.

[6] David, Huss, et al. "Development of otolith receptors in Japanese quail." Developmental Neurobiology 70.6(2010):436-455.

[7] Association, Japanese Gastric Cancer. "Japanese Classification of Gastric Carcinoma - 2nd English Edition -." Gastric Cancer 1.1(1998):10-24

[8] Higuchi, T., Seki, N., Kamizono, S., Yamada, A., Kimura, A., \& Kato, H., et al. (1998). Polymorphism of the $5^{\prime}$ - flanking region of the human tumor necrosis factor (tnf) - $\alpha$ gene in japanese. Tissue Antigens, 51(6), 605-612.

[9] Nobutaka H, Tohru K, Hiroto M, et al. Molecular genetic analysis of a novel Parkin gene in Japanese families with autosomal recessive juvenile parkinsonism: evidence for variable homozygous deletions in the Parkin gene in affected individuals.[J]. Annals of Neurology, 1998, 44(6):935-941.

[10] Kivohara Y, Fuiishima M, Yoshitake T, et al. 313Incidence and risk factors of vascular dementia and Alzheimer's Disease in a defined elderly Japanese population: the Hisayama study[J]. Neurobiology of Aging, 1996, 17(4):S79.

[11] Tinker, and N. John. "Intermarriage and Ethnic Boundaries: The Japanese American Case1." Journal of Social Issues 29.2(1973):49-66.

[12] Katayama, H. ,., Yamaguchi, K. ,., Kozuka, T. ,., Takashima, T. ,., Seez, P. ,., \& Matsuura, K. ,. (1990). Adverse reactions to ionic and nonionic contrast media. a report from the japanese committee on the safety of contrast media.. Radiology, 175(3), 621-8. 